AGRICA: Journal of Sustainable Drayland Agriculture, 14 (1): 59-66 (2021)

ISSN-Online: 2715-4955; ISSN-Cetak: 2715-6613

DOI: https://doi.org/10.37478/agr.v14i1.1037

\title{
POPULASI DAN TINGKAT SERANGAN HAMA KUTU PUTIH Dysmicoccus brevipes (Hemiptera : Pseudociccidae) PADA TANAMAN JAHE (Zingiber officinalle Rosc) DI DESA NUAMURI KECAMATAN KELIMUTU
}

\author{
Emilia H. Adus dan Yustina M.S.W Pu’u \\ Program studi Agroteknologi, Fakultas Pertanian Universitas Flores \\ Jln. Sam Ratulanggi XX Paupire, Ende, Nusa Tenggara Timur \\ yus_puu@yahoo.com
}

\begin{abstract}
Population and attack rate of the mealybug Dysmicoccus brevipes (Hemiptera: Pseudociccidae) on Ginger (Zingiber officinalle Rosc) In Nuamuri Village, Kelimutu District. This study aims to determine the population and level of attack of mealybug pests on ginger plants during harvesting in Nuamuri Village, Kelimutu District, Ende Regency. This research was carried out from February 2020 to July 2020, in Detubewa village, Nuamaro village and Nuamuri village. Observations were made by directly counting pests and damaged and attacked rhizomes, using the path method. Data analysis used is data obtained from the location of observations in tabulation based on the results of direct observations in the field. What was observed was the population and attack rate of each affected ginger planting location. The results showed that during the observation, the highest population of mealybugs was found in Detubewa village with 2,645 heads and the lowest value was in Nuamaro village, namely 2,127 heads, the highest pest population after Detubewa village was village Nuamuri with 2,478 individuals. Meanwhile, the attack rate and presentation of very heavy attacks were in Detubewa village by $84 \%$, and heavy attacks in Nuamuri village at $66 \%$ and Nuamaro village at $68 \%$.
\end{abstract}

Key words : Attack rate, Ginger, Mealbug, Population

\section{PENDAHULUAN}

Tanaman jahe (Zingiber officinale Rosc.) merupakan salah satu komoditas pertanian yang memanfaatkan umbinya sebagai sumber produksi (Sudana dan Lotrini, 2005; Miftahudin et al., 2011). Maka dari itu banyak dijumpai sentral penanaman jahe dilapangan yang dilakukan dengan teknik yang sama dan lahan yang berdekatan. Dapat diketahui bahwa lokasi budidaya suatu tanaman yang berdekatan juga dapat menimbulkan penyebaran hama, hal demikian dikarenakan penyebaran hama pada tanaman bisa saja terjadi melalui benih 
yang digunakan dan sangat bergantung pada kondisi lingkungan sekitar.

Desa Nuamuri merupakan salah satu sentra produksi jahe di Kabupaten Ende sejak tahun 1990. Pada saat itu petani membudidaya tanaman jahe merah dan sekitar tahun 1998 petani Desa Nuamuri mulai membudidaya tanaman jahe putih. Berdasarkan data yang diperoleh dari lapangan, pada tahun 2015 luasan lahan untuk pengembangan tanaman jahe di Desa Nuamuri sebesar 40 ha dengan produksi 15 ton/ha. Sehingga komoditi obat-obatan yaitu tanaman jahe telah mencapai produksi sebesar 600 ton (BPP Kecamatan Kelimutu. 2016). Produksi tanaman jahe tiga tahun terakhir mengalami penurunan yaitu 14,2 ton/ha pada tahun $2016,13,4$ ton/ha tahun 2017 dan 12 ton/ha tahun 2018. Faktor penyebab penurunan produksi pada komoditi jahe yaitu adanya serangan hama kutu putih pada rimpang tanaman jahe.

Berdasarkan hasil pengamatan dilapangan menunjukan bahwa serangan kutu putih ini telah menyebar diseluruh pertanaman jahe. Adapun hal lain yaitu dimana lahan yang digunakan juga tidak hanya untuk budidaya tanaman jahe tetapi juga digunakan untuk budiyaya tanaman seperti tanaman pangan dan tanaman hortikultura. Tetapi yang menjadi hambatan utama adalah hama kutu putih yang meyerang pada rimpang jahe.

Serangan hama kutu putih (Dysmicoccus brevipes) ini biasanya selalu menyerang pada daerah sub tropis sampai daerah tropis serta memiliki inang yang luas yaitu lebih dari 100 genus dari 53 famili (Dove, 2005; Mamahit et al., 2008; Williams dan Watson, 1988; CABI, 2003; Mau et al., 1992). Terdapat tiga spesies dari kerabat dekatnya famili Zingiberaceae yang termasuk dalam inang kutu putih antara lain adalah kunyit (Curcuma longa), jahe kuning (Hedychium flavum) dan jahe (Zingiber officinale). Beberapa faktor juga menjadi penyebab antara lain adalah adanya residu bahan kimia yang sudah terkontaminasi dengan tanah yang menimbulkan resistensi, resurgensi dan munculnya serangga sekunder atau hama baru pada komoditi pertanian (Nurindah, 2006).

Penyebaran hama ini meliputi hampir seluruh areal pertanaman jahe yang ada di Desa Nuamuri dengan serangan yang diperkirakan telah mencapai $30 \%$ pada tahun 2018. Serangan hama kutu putih (Dymicoccus brevipes) di Desa Nuamuri pada tiga dusun yakni Dusun Detubewa, Dusun Nuamaro dan Dusun Nuamuri Kecamatan Kelimutu Kabupaten Ende dimana petani membudayakan tanaman jahe 
Adus : Populasi dan tingkat serangan hama kutu putih pada tanaman jahe

pada lahan yang berdekatan dan juga ditanami tanaman lain seperti jenis hortikultura serta tidak terawat dengan baik. Sehingga hal demikian dapat menimbulkan serangan hama kutu putih semakin tinggi dari tahun ke tahun. Berdasarkan hasil survei di Desa Nuamuri pada tiga lokasi penamanan jahe diketahui bahwa rerata populasi hama kutu putih pada tanaman jahe saat panen yaitu pada Dusun Detubewa sebanyak 1.324, Dusun Nuamuri sebanyak 1.064 dan Dusun Nuamaro sebanyak 1.239 ekor.

Perkembangan populasi suatu jenis hama atau spesies yang hidup dan berasosiasi dengannya merupakan suatu informasi penting dalam rangka pengelolaan dan pengendalian suatu hama. Secara umum diketahui bahwa populasi suatu spesies pada suatu pertanaman tergantung pada stadia pertumbuhan tanaman, jumlah tanaman dan cara bertanam (Hasibuan, 2005). Semakin bertambahnya populasi hama akan mempengaruhi tingkat serangan terhadap tanaman yang menjadi inang dari hama tersebut (Deptan, 2006). Berdasarkan data dari lapangan, luasan serangan yang disebabkan oleh hama kutu putih sudah meningkat dimana hampir seluruh areal pertanaman jahe diserang hama tersebut.

Peningkatan produksi sangat diutamakan untuk menunjang kebutuhan ekonomi masyarakat serta besarnya permintaan jahe terkait dengan manfaat empiris bagi kesehatan yang telah teruji secara ilmiah (Melati, 2015) maka dari itu, perlu dilakukan pengendalian dengan tepat, efektif, praktis dan ekonomis namun efektifitasnya tinggi serta aman bagi lingkungan yang setidaknya dapat meminimalkan populasi dan serangan hama kutu putih tersebut. Penelitian ini bertujuan untuk mengetahui populasi dan intensitas serangan hama kutu putih pada tanaman jahe di Desa Nuamuri Kecamatan Kelimutu

\section{BAHAN DAN METODE}

Penelitian ini dilakukan di Desa Nuamuri Kecamatan Kelimutu Kabupaten Ende. Penelitian ini dilakukan dari bulan Februari sampai Juli 2020. Penelitian ini menggunakan metode survei di tiga dusun yaitu Dusun Watubewa, Dusun Nuamaro dan Dusun Nuamuri Desa Nuamuri Kecamatan Kelimutu. Bahan yang digunakan dalam penelitian adalah rimpang tanaman jahe, dan hama kutu putih (Dysmicoccus brevipes), alkohol $70 \%$, toples, tali rafia dan kayu patok. Sedangkan alat yang akan digunakan dalam penelitian ini adalah alat tulis, tofa, pisau kater, kuas, kamera dan meter. Luasan lahan pengamatan $10 \mathrm{~m}$ x $10 \mathrm{~m}$. Pengambilan sampel dilakukan dengan menggunakan metode secara purposive atau sengaja. 


\section{Parameter Pengamatan}

\section{Populasi hama kutu putih}

Pengamatan dilakukan secara langsung yaitu diamati adanya imago kutu putih yang menyerang pada rimpang tanaman jahe. Total populasi Kutu putih (Dysmicoccus brevipes) (ekor) dengan jumlahkan setiap pertanaman sampel. Rata-rata populasi hama dihitung dengan menggunakan rumus:

$$
\mathrm{P}=\frac{n}{N}
$$

Keterangan :

$\mathrm{p}=$ Populasi serangga hama

$\mathrm{n}=$ Jumlah serangga hama yang ditemukan

$\mathrm{N}=$ Jumlah pengambilan sampel

\section{Intensitas Serangan}

Parameter yang diamati dalam penelitian ini adalah dengan menjumlahkan rimpang yang terserang hama kutu putih (Dysmicoccus brevipes) pada tanaman jahe. Untuk menghitung intensitas serangan dengan cara melihat kerusakan yang disebabkan oleh kutu putih dengan menggunakan rumus:

$$
\mathrm{I}=\frac{\mathrm{a}}{\mathrm{b}} \times 100 \%
$$

Keterangan :

I = Intensitas serangan

a =Jumlah rimpang yang rusak $\mathrm{b} \quad=$ Jumlah rimpang yang diamati

Kategori serangan:

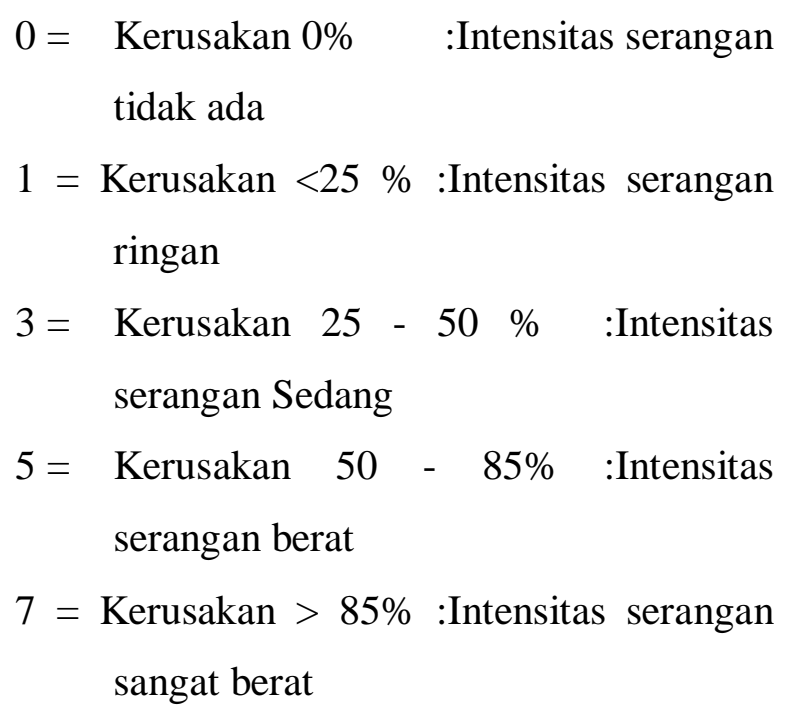

\section{Analisis Data}

Data yang diperoleh dari lokasi penelitian ditabulasi dengan menggunakan rumus populasi dan intensitas serangan kemudian dideskripsi sesuai dengan variabel pengamatan yang ditentukan.

\section{HASIL DAN PEMBAHASAN}

Hasil penelitian populasi dan tingkat seranganhama kutu putih (Dysmicoccus brevipes) di Desa Nuamuri Kecamatan kelimutu yang terdiri dari tiga lokasi yaitu Dusun Detubewa, Dusun Nuamaro dan Dusun Nuamuri berbeda-beda (Tabel 1). 
Adus : Populasi dan tingkat serangan hama kutu putih pada tanaman jahe

Tabel 1. Populasi dan Intensitas Serangan Imago Kutu Putih (Dysmicoccus brevipes) Pada Tanaman Jahe Desa Nuamuri Kecamatan Kelimutu

\begin{tabular}{ccccc}
\hline Lokasi & $\begin{array}{c}\text { Populasi } \\
(\text { Ekor/m2) }\end{array}$ & $\begin{array}{c}\text { Rataan } \\
\text { Populasi (Ekor) }\end{array}$ & $\begin{array}{c}\text { Intensitas } \\
\text { serangan }(\%)\end{array}$ & kategori serangan \\
\hline Detubewa & 2.645 & 1.324 & 84 & Sangat Berat \\
Nuamuri & 2.127 & 1.064 & 66 & Berat \\
Nuamaro & 2.478 & 1.239 & 68 & Berat \\
\hline
\end{tabular}

Hasil penelitian menunjukan bahwa pada Dusun Detubewa memiliki populasi hama kutu putih yang tertinggi sebesar 2.645 ekor dengan intensitas serangan sangat berat sebesar $84 \%$ dengan jumlah rimpang yangrusak atau terserang sebesar 146 dan sehat sebanyak 21 rimpang. Populasi hama kutu putih yang tinggi pada Dusun Detubewa disebabkan karena lahan yang sejak lama digunakan untuk budidaya tanaman jahe, sejak tiga tahun terakhir mulai digunakan untuk budidaya tanaman sayuran seperti tanaman hortikultura dan ditanami tanaman pangan seperti ubi kayu. Lahan budidaya tanaman jahe sejak dulu umumnya belum ada sentuhan teknologi baik itu dalam hal pengolahan lahan sampai pada pengendalian hama maupun penyakit pada tanaman jahe. Sementara sejak adanya alih fungsi lahan sentuhan teknologi mulai diterapkan. Karena adanya desakan lahan yang kuat sementara luas lahan yang semakin terbatas maka munculah suatu kegiatan alih fungsi lahan yang dapat menyebabkan pencemaran pada tanah yang berdampak pada munculnya hama baru pada tanaman (Sartiami, 2006). Selain itu populasi yang tinggi di Dusun detubewa juga disebabkan karena dilahan yang sama juga terdapat tanaman inang dari hama kutu putih tersebut salah satunya adalah tanaman kencur dan jahe merah. Populasi hama yang tinggi akan berpengaruh terhadap tingkat serangan hama, seperti halnya pada Dusun Detubewa intensitas serangan hama yang sangat berat disebabkan karena pembersihan gulma juga tidak sering dilakukan dan didalam lahan budidaya yang sama terdapat tanaman lain seperti tanaman sayuran. Serta lokasi ini merupakan lokasi yang sejak dulu dijadikan lokasi untuk budidaya tanaman jahe dan merupakan lokasi yang pertama munculnya hama kutu putih (Dysmicoccus brevipes) dan lokasi tersebut yang berkaitan dengan alih fungsi lahan bahwa sudah pernah menggunakan bahan kimia.

Populasi hama yang ada di dua dusun yakni dusun Nuamuri dan dusun Nuamaro 
yang memiliki populasi hama sebesar 2.478 ekor dan presentasi kerusakan sebesar $68 \%$. Keduanya sama-sama memiliki kategori intensitas serangan berat. Dusun Nuamuri berdasarkan hasil penelitian juga merupakan lokasi dengan memiliki populasi hama yang terendah sebesar 2.127 ekordengan presentasi serangan sebesar 66\% dengan jumlah yang rusak 93 dan sehat 45 rimpang. Populasi hama yang berkurang atau rendah di Dusun Nuamuri karena pola tanam yang diterapkan masih teratur misalnya yang berkaitan dengan jarak tanam maupun alih fungsi lahan belum ada. Serangan sedang pada lokasi tersebut yang terjadi disebabkan karena adanya penggunaan benih dari luar dan lokasi tersebut berdekatan dengan lokasi penanaman jahe yang lain yang notabene sudah terkontaminasi dengan hama kutu putih tersebut. Intensitas serangan berat terjadi disebabkan karena dalam pengolahan lahan seperti pengendalian gulma tidak dilakukan sejak selesai penanaman hingga sampai panen. Pengendalian gulma semestinya dilakukan ketika tanaman jahe berumur dua sampai tiga minggu kemudian dilanjutkan tiga sampai enam minggu sekali (Triyono, 2018) dan dalam lahan budidaya tanaman jahe masih ada tanaman lain yang ditanam seperti tanaman pepaya (Mamahit et al., 2010).
Populasi hama yang berada di alam tidaklah menetap. Dalam sekali waktu populasi hama bisa saja tinggi dan bisa juga rendah. Adanya perbedaan yang berkaitan dengan populasi hama di lahan budidaya disebabkan karena kondisi lingkungan seperti salah satunya adalah cuaca, alih fungsi lahan, kulalitas benih serta keberadaan makanan dari hama tersebut (Ermiati, 2010). Kondisi lingkungan yang mendukung dapat meningkatkan populasi hama pada suatu areal pertanian. Salah satunya adalah keaadan iklim misalnya pada keadaan kelembaban tanah yang kering. Kelembaban tanah yang berada dilokasi pengamatan yang kering akibat kemarau panjang menyebabkan populasi hama semakin meningkat ( Erni, 2018).

Populasi hama kutu putih (Dysmicoccus brevipes) lebih banyak pada saat musim kering. Hal demikian terjadi karena kutu putih tersebut bertahan hidup dibagian rimpang tanaman jahe sehingga dengan kondisi tanah yang kering akan memudahkan hama tersebut berkembangbiak. Hal lain yang dapat mendukung perkembangan populasi dari hama kutu putih (Dysmicoccus brevipes) adalah salah satu kegiatan pertanian yaitu alih fungsi lahan (Wiryono, 2011). Begitu pula yang berkaitan dengan intensitas 
Adus : Populasi dan tingkat serangan hama kutu putih pada tanaman jahe

serangan, semakin tinggi populasi hama pada suatu areal pertanian maka tingkat serangan hama akan semakin besar.

\section{SIMPULAN}

Populasi hama kutu putih tertinggi terdapat di Dusun Detubewa sebesar 2.645 ekor kutu putih dan nilai populasi hama yang terendah berada di Dusun Nuamuri sebesar 2.127 ekor. serta diketahui populasi hama di Dusun Nuamaro dengan populasi hama sebesar 2.478 ekor. Dusun Detubewa memiliki presentase serangan yang memiliki presentasi serangan hama yang tinggi dengan intensitas serangan sangat berat sebesar $84 \%$. Sedangkan presentase serangan hama kutu putih yang terendah terdapat di Dusun Nuamuri dengan intensitas berat sebesar 66\% dan Dusun Nuamaro dengan intensitas serangan yang berat sebesar $68 \%$.

\section{UCAPAN TERIMA KASIH}

Pada kesempatan ini kami mengucapkan terima kasih kepada semua pihak yang telah membantu dalam pelaksanaan penelitian ini yakni civitas akademika Fakultas Pertanian Universitas Flores.

\section{DAFTAR PUSTAKA}

CABI (Centre for Agriculture and Bioscience International). 2003. Crop Protection Compendium. Welingfort.
Nosworthy Way. Wallingfort. Oxfordshire. OX10 8DE. 7 p.

Ermiati. (2010). Analisis Kelayakan dan kendala Pengembangan Usaha Tani Jahe Putih kecil Di Kabupaten Sumedang (studi Kasus Kecamatan Cimalaka Kabupaten Sumedang). Bul. Litro, 21(1), 80-92.

Hasibuan. (2005). Hubungan kutu Dompolan Dysmicoccus brevipes (CKLL) (Homoptera:Pseuudoccocidae) Dan Semut Api Solenopsis Sp.(Hymepnoptera:Formicidae) Pada Dua Cara Bertanam Nenas. J. HPT Tropika, 5(1), 17-23.

Mamahit, Juliet M. Eva., Manuwoto, S., Hidayat, P., Sobir., 2008. Biologi Kutu Putih Dysmicoccus brevipes Cockerell

(Hemiptera:Pseudococcidae) Pada Tanaman Nenas dan Kencur. Bul. Littro. 19 (2). 164-173.

Mamahit, Juliet M. Eva., Manengkey, G.S.J., Makal, H.V.G. 2010. Kelimpahan Populasi Kutu Putih Dysmicoccus sp. (Hemiptera:Pseudococcidae) Pada Tanaman Nenas di Kabupaten Bolaang Mongondowo. Eugenia. 16 (3). 161-167.

Mau, R. F. L. \& J. L. M. Kessing. 1992. Dysmicoccus brevipes (Cockerell). 
Honolulu, Hawaii: Department of Entomology.

Melati, A. D. S. (2015). Karakter Fisisk Dan

Fisiologis Jenis Rimpang Serta Korelasinya Dengan Viabilitas Benih Jahe Putih Besar (Zingiber officinale Rosc) (p. jurnal litri ,vol 21(2) hlm.89-98). p. jurnal litri ,vol 21(2) hlm.89-98.

Miftahudin., Efiana. 2011. Bunga Rampai Jahe (Zingiber officinale Rosc.) Status Teknologi Hasil Penelitian Jahe. Balai Penelitian Tanaman Obat dan Aromatikpusat Penelitian dan Pengembangan Perkebunan Badan Penelitian dan Pengembangan Pertanian Kementerian Pertanian. 162 hal.

Nurindah. (2006). Pengelolaan

Agroekosistem dalam Pengendalian Hama. Perspektif, 5(2), 78-85.

Sartiami, D. (2006). Keberadaan Dysmicoccus brevipes (Cockerell) (HEMIPTERA : Pseudoccocidae) Sebagai Vektor Pineapple Mealybug Wilt-associated Virus (PMVAW) Pada Tanaman Nenas. J.II.Pert.
Indon, 11(1).

Sudana, M., \& Lotrini, M. (2005). Pengendalian terpadu penyakit layu (Ralstonia solanacearum. J.HPT Tropika, 5(2), 97-103.

Susanti Erni. (2018). Parameter Iklim sebagai Indikator Peringatan Dini Serangan Hama Penyakit Tanaman. Sumber Daya Lahan, 12(1), 59-70.

Triyono, sumarni. (2018). Budidaya Tanaman Jahe Di Desa Plesungan Kecamatan Gondangrejo Kab. Karanganyar Provinsi Jawa Tengah. ADIWIDYA, II (November), 1-9.

Williams, D.J. and G.W.Q. Watson. 1988. The Mealybug (Pseudococcidae). $\mathrm{CAB}$ International Institute of Entomology. London. 260p.

Wiryono. (2011). Alih Fungsi Lahan Pertanian Pangan Ditinjau dari Aspek Ekologis. Prosiding Seminar Nasional, (Oktober). 